\title{
The Effectiveness Of Thailand-Laos Border Trade Strategic Management
}

\author{
Sr. Col. Somchart Nanudorn, North Eastern University, Thailand \\ Sorachai Phisanbutr, Dhurakij Pundit University, Thailand \\ Buddhagarn Rutchatorn, Chulalongkorn University, Thailand \\ Thitaporn Phuboonbutr, North Eastern University, Thailand \\ Thongphon Promsaka Na Sakolnakorn, Prince of Songkla University, Thailand
}

\begin{abstract}
The objective of this study is to study the management strategy applied to the Thailand-Laos border trade. This study was conducted in the years 2010 and 2011. The areas under study were Nong Khai, Nakhon Phanom, and Mukdahan provinces in the northeast of Thailand with the application of a mixed-methods research methodology including both quantitative and qualitative methods. Using the quantitative method, we provided 352 questionnaires to entrepreneurs who conducted cross-border trade through the customhouses in these provinces. We analyzed this data using means, percentages, factor analysis, and regression analysis. Using the qualitative method, we conducted a focus group of 16 key participants, such as entrepreneurs, customs officers, directors, and officers of the Office of Provincial Commerce, as well as the management team of the Provincial Chamber of Commerce. We analyzed this data using content analysis and descriptive analysis. On the basis of our analysis, we determined guidelines for the strategic management of cross-border trade between Thailand and Laos. The first strategy we suggest is that both Thailand and Laos should solve any border-trade problems together. The second is that border trade management should have only one unit and/or department with management authority. Currently many units and departments are involved in managing cross-border trade. Moreover, before opening a new port of entry, both governments should prepare all facilities and train officers and entrepreneurs to gain more knowledge about relevant laws, as well as providing resources for new officers in order to avoid problems of insufficient status and lag in crossing. One-stop service points should be created at customhouses to avoid long customs lines. Equipment such as X-ray trucks should be provided to support one-stop service to increase convenience and effectiveness as a way to avoid a situation where traders circumvent the law by not declaring goods at customs.
\end{abstract}

Keywords: Thailand-Laos Border Trade Strategic Management

\section{INTRODUCTION}

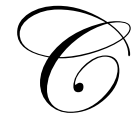

ross-border trade is defined as the flow of goods and services across international land borders within a range of up to 30 kilometers. The unique feature of cross-border trade is geographical proximity, which renders transportation costs almost irrelevant, thereby allowing traders to take advantage of differences in the supply, demand, and prices of various goods and services available on either side of the border (World Bank, 2007: 4).

Cross-border trade is an important aspect of international trade; worldwide cross-border trade is about US\$720 billion (UNCTAD, 2000). Currently, globally is the most powerful political economic and social trend. However, in Hoon-Ho and Selmier's study on cross-border trade in Asia, they found that AFTA not only increases regional economic interdependency through institutional agreements; it also increases trade with non-member countries (Hoon-Ho \& Selmier, 2008). 
Thailand and Laos have had a good relationship historically, commercially, and from an investment perspective. Laotian trade is extensively connected to Thailand. The five main import and export areas between the countries are as follows: (1) consumer products; (2) agricultural products and agricultural machinery; (3) construction products and materials; (4) vehicles and parts; and (5) health services and other services (OSMEP, 2011).

Rapidly changing economic and demographic structures in both Laos and Thailand have strong implications for efforts to increase trade between the countries. Laos is an agriculture-based economy; the agricultural sector is its largest economic sector (Asian Development Bank, 2006). In the year 2004, 60.3\% of Laos's exports and 30.7\% of its imports were respectively to and from Thailand (UNDP, 2006: 22). Cross-border trade between Thailand and Laos through Mukdahan province in the northeast of Thailand in August 2008 alone amounted to $\$ 70.6$ million, an increase of $19 \%$ over the same period in 2007. Of this amount, \$26.8 million was accounted for by Thai exports to Laos, while $\$ 45.1$ million involved imports from Laos (Public Relations Department of the Government of Thailand, 2012). The value of Thai-Laotian trade at the Friendship Bridge border checkpoint in Nong Khai province on the Mekong River in 2011 reached \$1.4 billion USD (MCOT, 2011).

The Thai-Laotian border trade has many problems. For example, many traders are local traders with no professional education in marketing management. Another problem is that Thai products sold in Laos cost more than Chinese goods. Moreover, the logistic infrastructure in Laos is poor, and its international trade is unstable; rules and policies change often (Maneerat, 2012). In addition, the poor condition of roads and highways in Laos is a significant problem that affects transportation of goods and products from Thailand (Manager Daily, 2012).

Despite these problems, however, the Thai-Laotian border trade is important in generating economic growth in both countries. In this study, we pose the following research questions: (1) what are the problems faced by cross-border trade between Thailand and Laos? (2) what are the management strategies being applied to the ThaiLaotian cross-border trade?

\section{OBJECTIVES}

To study the management strategies being used in the Thai-Laotian border trade.

\section{METHODOLOGY}

This study was conducted in the years 2010 and 2011. The areas of focus were Nong Khai, Nakhon Phanom, and Mukdahan provinces in the northeast of Thailand; both a quantitative and a qualitative method were applied.

Using the quantitative method, we calculated sample size as per Yamane (1973) and provided 352 questionnaires to entrepreneurs operating in the Thai-Laos border area, specifically in Nong Khai, Nakhon Phanom, and Mukdahan provinces in the northeast of Thailand. We analyzed the data using means, percentages, factor analysis, and regression analysis.

Using the qualitative method, we conducted a focus group of 16 key informants, including entrepreneurs, customs officers, directors, and officers of the Office of Provincial Commerce and the management team of the Provincial Chamber of Commerce. We performed content and descriptive analyses on this data.

\section{RESULTS}

We found that most entrepreneurs in the region are male (59.30\%), and that entrepreneurs between 31 and 40 years old account for $30.70 \%$ of the total and entrepreneurs between the ages of 41 and 50 years $28.0 \%$. Among the respondents, $32.90 \%$ have a diploma and $30.40 \%$ have a bachelor's degree. With regard to income, $37.30 \%$ have an income between $\$ 320$ and $\$ 1,000$ per month, and 24.50\% have an income between $\$ 1,001$ and $\$ 1,600$ per month. In addition, entrepreneurs who do business in the service sector account for $50.60 \%$ of the total, and traders account for $21.70 \%$. Those who have operated their business for between one and five years account for $34.20 \%$ of the total; $64.3 \%$ use cash to buy and sell goods. Those who use Thai baht as the currency of daily business account for $96.30 \%$. 
About $49.10 \%$ of the entrepreneurs are satisfied with the Thai government's policies to encourage ThaiLaotian border traders; $42.90 \%$ are satisfied with the Thai government's official involvement with the Thai-Laotian border trade. Satisfaction with the one-stop service system is $33.20 \%$; satisfaction with the government implementation of border-trades rules and policies is $79.30 \%$. Satisfaction with collaboration between government and entrepreneurs for the Thai-Laotian border trade management is $61.80 \%$.

Regarding satisfaction with the border-trade management strategy of the Thai government, we found that satisfaction with the ability of the Thai government to appropriately price goods and products is high $(\mathrm{mean}=3.53)$. Satisfaction with the ability of Thai entrepreneurs to export goods and products to meet the requirements of Laotian consumers is moderate (mean $=3.31$ ); and satisfaction that prices are impartial and standardized is moderate (mean =3.38). Satisfaction with Thai government's resources devoted to cross-border trade is moderate (mean $=3.26)$, and satisfaction with the Thai government's activities setting up marketing promotions for Thai products is high (mean $=$ 3.57). Satisfaction with knowledge-sharing between traders, government agencies, and the local community is high $($ mean $=3.52)$; satisfaction with level of social responsibility demonstrated among traders is high $($ mean $=3.51)$. Satisfaction with environmental and pollution protection is moderate (mean $=3.34$ ); costs of doing business and their reflection in prices is high (mean $=3.57$ ). The price of goods related to the income of local people is moderate $($ mean $=3.40)$, and the degree to which product quality is conducive to cross-border trade is high $($ mean $=3.90)$. The degree to which entrepreneurs attempt to subcontract in local communities is high (mean $=3.63$ ).

We performed factor analysis to analyze the variables that affect Thai-Laotian border trade, which we can divide into eight groups, as shown in Table 1:

Table 1 Factor analysis of variables affecting cross-border trade between Thailand and Laos

\begin{tabular}{|c|c|c|c|}
\hline Factor $(\mathbf{X})$ & Name of variable & Extraction & Factor \\
\hline \multirow[t]{5}{*}{ Product $(\mathrm{X} 1)$} & -Packaging is attractive to consumers & .619 & .668 \\
\hline & -Products are fresh and new & .758 & .700 \\
\hline & -Quality of products is high & .759 & .647 \\
\hline & -A wide range of products and packaging is provided & .796 & .784 \\
\hline & -Shops are designed and laid out in an appealing manner & .659 & .705 \\
\hline \multirow[t]{6}{*}{ Price $(\mathrm{X} 2)$} & -Retail prices are appropriate & .730 & .769 \\
\hline & -Wholesale prices are appropriate & .680 & .757 \\
\hline & -The same products are priced differently between shops, making possible & & \\
\hline & price comparison & 670 & .760 \\
\hline & -Price tags are clear and easy to see & .614 & .737 \\
\hline & -Goods are flexibly priced and negotiation is possible & .752 & .814 \\
\hline \multirow[t]{3}{*}{ Place (X3) } & $\begin{array}{l}\text {-Many middlemen come to cross-border areas to buy and sell goods and } \\
\text { products }\end{array}$ & .702 & .366 \\
\hline & -Government has made available adequate customs and ports of entry & .628 & .419 \\
\hline & -Logistics system is convenient & .705 & .696 \\
\hline \multirow{4}{*}{$\begin{array}{l}\text { Marketing Promotion } \\
\text { (X4) }\end{array}$} & -Entrepreneurs market their products on festival days and event days & .625 & .740 \\
\hline & -Salesman effectively motivate customers to buy & .708 & .796 \\
\hline & -Marketing promotions such as sales discounts and free samples occur & .681 & .807 \\
\hline & - advertised by telephone & .651 & .785 \\
\hline \multirow[t]{6}{*}{ Stakeholders (X5) } & $\begin{array}{l}\text {-Entrepreneurs promote understanding about cross-border trade in local } \\
\text { communities }\end{array}$ & .679 & .575 \\
\hline & -Entrepreneurs advertise their activities in local communities & .673 & .596 \\
\hline & $\begin{array}{l}\text {-Entrepreneurs give opportunities to community members to present their } \\
\text { ideas about cross-border trade }\end{array}$ & 603 & .601 \\
\hline & -Entrepreneurs share knowledge with the community & .574 & .551 \\
\hline & -Entrepreneurs brainstorm for product development & .682 & .554 \\
\hline & $\begin{array}{l}\text {-Entrepreneurs support local people to gain more income and develop } \\
\text { household businesses }\end{array}$ & .714 & .376 \\
\hline \multirow[t]{4}{*}{ Resources (X6) } & -Entrepreneurs are concerned with environmental protection & .658 & .507 \\
\hline & -Entrepreneurs encourage the community to protect the environment & .664 & .577 \\
\hline & -Entrepreneurs have pollution management systems & .579 & .641 \\
\hline & -Entrepreneurs have recycling and reusing protocols & .685 & .640 \\
\hline
\end{tabular}

(table continues on next page) 
Table 1 continued

\begin{tabular}{|c|c|c|c|}
\hline Factor $(\mathbf{X})$ & Name of variable & Extraction & Factor \\
\hline Resources (X6) & $\begin{array}{l}\text {-Entrepreneurs collaborate with the local community for environmental } \\
\text { protection }\end{array}$ & .639 & .527 \\
\hline Profit (X7) & $\begin{array}{l}\text {-Entrepreneurs maintain low prices for local community } \\
\text {-Entrepreneurs are concerned with community satisfaction } \\
\text {-Entrepreneurs sell goods at prices suitable to local incomes } \\
\text {-Entrepreneurs give back to society, for example through financial support } \\
\text { for community activities }\end{array}$ & $\begin{array}{l}.651 \\
.658 \\
.656\end{array}$ & $\begin{array}{l}.491 \\
.603 \\
.677\end{array}$ \\
\hline $\begin{array}{l}\text { Faith, moral and and } \\
\text { creative thinking (X8) }\end{array}$ & $\begin{array}{l}\text {-Product quality is important for cross-border trade sustainability } \\
\text {-Cross-border trade under the rule of law benefits the economy } \\
\text {-Government should study cross-border trade to determine who is not } \\
\text { trading under the rule of law } \\
\text {-Entrepreneurs encourage local communities to accept subcontracted work } \\
\text { from the entrepreneurs }\end{array}$ & $\begin{array}{l}.780 \\
.800 \\
.770\end{array}$ & $\begin{array}{l}.663 \\
.664\end{array}$ \\
\hline
\end{tabular}

In addition, we performed a regression analysis to predict entrepreneurs' satisfaction with the Thai-Laotian border trade, as shown in Table 2:

Table 2 Regression analysis to predict entrepreneurs' satisfaction with cross-border trade

\begin{tabular}{|c|c|c|c|c|c|}
\hline Variables & $b$ & $\mathbf{S E}_{b}$ & $\beta$ & $t$ & $p$ \\
\hline 1. Product $(\mathrm{P} 1)$ & -.236 & .130 & -.168 & -1.812 & .071 \\
\hline 2. Price $(\mathrm{P} 2)$ & -.297 & .133 & -.169 & -2.227 & $.027 *$ \\
\hline 3. Places (P3) & .108 & .135 & .057 & .802 & .423 \\
\hline 4. Marketing promotion ( $\mathrm{P} 4)$ & -.046 & .125 & -.030 & -.366 & .715 \\
\hline 5. Stakeholders (P5) & -.153 & .155 & -.082 & -.985 & .325 \\
\hline 6. Resources (P6) & .425 & .147 & .238 & 2.885 & $.004 *$ \\
\hline 7. Profit (P7) & .351 & .134 & .215 & 2.629 & $.009 *$ \\
\hline 8. Faith, moral and creative thinking (P8) & .461 & .090 & .367 & 5.111 & $.000 *$ \\
\hline
\end{tabular}

Constant $1.623 ;$ SE. $={ }_{\text {est }} 402$

$R .=439 * ; R^{2}=.193 ; F=9.360 ; p=.000 *$

$$
* p<0.05
$$

From Table 2, we found that eight factors are related to marketing satisfaction. The multiple correlation coefficient is .439 and the level of statistical significance is 0.05 , with SE at .402. In the regression correlation, the highest value is for Faith, moral and creative thinking (P8), whose $\beta$ is .367. For Resources (P6), $\beta$ is .283; for Profit (P7), it is. 215; for Places (P3), .057; for Marketing promotion (P4), -.030; for Stakeholders (P5), -.082; for Product (P1), -.168 ; and last, for price (P2), $\beta$ is -.169 , with statistical significance set at the 0.05 level.

From this analysis, we found three factors that predict satisfaction with Thai-Laotian border trade management: Resources (P6), Profit (P7), and Faith, moral and creative thinking (P8). The following equation predicts entrepreneur satisfaction:

$$
\hat{Y}=1.623+.425 P 6 *+.351 P 7+.461 P 8 *
$$

After we performed the quantitative analysis, we performed a qualitative analysis with a focus group made up of people involved in the Thai-Laotian border trade. Sixteen people from customhouses, local government, immigration police, the Office of Provincial Commerce, and the management team of the Provincial Chamber of Commerce were recruited to study the strategic guidelines for management of cross-border trade between Thailand and Laos. We can conclude as follows: 
1. Thailand and Laos should solve any problems in cross-border trade together.

2. Thai-Laotian border-trade management should have only one unit and/or department with management authority. Currently many units and departments are involved.

3. Before opening a new port of entry between Thailand and Laos, both governments should prepare facilities, make provisions to address logistic requirements, and secure water supply, electrical supply, and budget. In the past, when starting a new port of entry these needs have not been addressed.

4. More officials such as immigration police and customhouse officers are needed, on both the Thai and Laotian sides.

5. A parking place for trucks and other vehicles awaiting custom checks should be prepared.

6. Both the Thai and Laotian governments should provide equipment such as truck X-rays and a modern computer system to facilitate cross-border trade.

7. Both governments should crack down on extra-legal trade.

8. Both governments should train both officials and entrepreneurs to know more about the relevant laws.

9. Both governments should resolve problems of homeland security together (e.g., drugs, illegal migration, car theft).

10. Both governments should set up information centers to provide knowledge and information to traders.

11. Both governments should operate under the framework of AFTA (ASEAN Free Trade Area).

12. A one-stop service system is important for customhouses on both the Thai and Laotian sides.

Regarding the guideline for the strategy management of cross-border trade between Thailand and Laos PDR, we reach the following conclusion. The first strategy was that both Thai and Laos PDR should resolve any issues related to border trade together. The second strategy was that border trade management should have only one authoritative unit and/or department. Currently, many units and departments are involved in managing cross-border trade. Moreover, before opening a new port, both governments should prepare all the facilities and train their officers and entrepreneurs to gain more knowledge about the rule of law and regulation. New officers should be hired to avoid shortage in staff (e.g., immigration police and customhouse officers). A one-stop service point should be created at the customhouse between Thai and Loas LDR to avoid a queue of traders waiting for a custom check. Equipment such as a truck X-ray should be provided to support the realistic one-stop service and avoid traders who breach the rule of law and do not declare goods to the customhouse.

\section{CONCLUSION}

Cooperation and information- and knowledge-sharing between Thailand and Laos is important in solving border-trade problems together. Portney (2005) states that participation is the best way to achieve sustainable development. Management of cross-border trade between Thailand and Laos must be examined closely and in the context of many non-trade issues to achieve the goal of effective management. Many stakeholders are paying the price of current illegal or informal border trade. A strategic management plan for cross-border trade is required to support economic growth. Sridharan et al. (2007) explain that a development plan is important for sustainability to guide operations.

Traders who do not abide by the rule of law damage the operations of traders who operate legally. For economic growth in both countries, their governments should support local businesses and community involvement as subcontractors to larger enterprises. Promsaka Na Sakolnakorn (2011) suggests that these local subcontractors can bring in extra household income and thus increase their quality of life.

\section{POLICY IMPLICATIONS}

From this study, we make the following suggestions for government policy: (1) The Thai and Laotian government should set up training and communications centers to disseminate knowledge about regulations relating to cross-border trade to all stakeholders, such as Thai and Laotian government agencies, entrepreneurs, and companies providing logistics support; (2) Thailand and Laos should engage in more collaboration at all levels of government from local to central; (3) Laos should improve its trade law and regulations; and (4) Thailand and Laos should set up policies for cross-border trade together. 


\section{FUTURE STUDY}

For future study, the strategic management of cross-border trade between Thailand and Laos in other region, such as in the north of the country should be compared to the findings of study. Culture, tradition, and attitudes that affect cross-border trade should also be studied. Finally, research collaboration between Thai and Laotian scholars is important to solving problems and developing sustainability together.

\section{AUTHOR INFORMATION}

Sr. Col. Dr. Somchart Nanudorn is 3rd Regimental Commanding Officer in Royal Thai Army Region 2. He received his Doctor of Business Administration degree from North Eastern University in Khon Kaen, his master's degree in sociology from Khon Kaen University, and his bachelor's degree from Chulachomklao Royal Military Academy. He is a specialist in homeland security and cross-border trade management.

Dr. Sorachai Phisanbutr is an Associate Professor at Dhurakij Pundit Universityin Bangkok . He received his PhD in Statistics from Oklahoma State University. He specializes in research methodology.

Dr. Buddhagarn Rutchatorn is an Associate Professor of Economics at Chulalongkorn University in Bangkok. He received his $\mathrm{PhD}$ in Economics from Keio University in Tokyo. He is a specialist in economic issues.

Dr. Thitaporn Phuboonbutr is a lecturer at North Eastern University Thailand. She received her PhD in Business Administration and Management from Walden University in Minneapolis and MBA from Roosevelt University in Chicago. She specializes in business management and cross-border trade strategy.

Dr. Thongphon Promsaka Na Sakolnakorn is a lecturer with the Faculty of Liberal Arts and Director of the Research Center for Asia Pacific Development Studies at Prince of Songkla University, Thailand. He received his first $\mathrm{PhD}$ in Development Science from Khon Kaen University, and his second doctoral degree, in Ancient Indian and Asian Studies, from Magadh University in Bodh Gaya, India. He specializes in outsourcing management, organization development, public policy, and SME management. E-mail: deaw_t@hotmail.com; thongphon.p@psu.ac.th. Corresponding author.

\section{REFERENCES}

1. $\quad$ Asian Development Bank. 2006. Asian Development Bank—Key Indicators 2006. Manila: Asian Development Bank.

2. Hoon-Ho, C. \& Selmier, W. Travis II. 2008. Expanding international trade beyond the RTA border: The case of ASEAN's economic diplomacy. Economics Letters, 100(3), 385-387.

3. Manager Daily. 2012. Year 2012, Border Trade Boom, Tourism Boom. Retrieved on February 10, 2012, from http://www.manager.co.th/mgrweekly/ViewNews.aspx?NewsID=9550000001570

4. Maneerat, N. 2012. Problem Issues in Thailand and Lao PDR Trade. Retrieved on February 12, 2012, from http://www.gotoknow.org/blog/export/111489

5. OSMEP. 2011. SMEs and Entering the ASEAN Community. Retrieved on February 11, 2012, from http://www.sme.go.th/SiteCollectionDocuments/White\%20Paper/2552/Eng 06.pdf

6. Portney, K. 2005. Civic Engagement and Sustainable Cities in the United States. Public Administration Review, 65(5), 579-591.

7. Promsaka Na Sakolnakorn, T. 2011. Economic and Social Development by Management Using Outsourcing and Subcontracting Strategies. The International Journal of Environmental, Cultural, Economic \& Social Sustainability, 7(5), 273-286.

8. Public Relations Department of the Government of Thailand. 2012. Thai-Lao Border Trade in the Northeastern Province of Mukdahan Is on the Rise. Retrieved on February 10, 2012, from http://thailand.prd.go.th/view_inside.php?id=4007

9. Sridharan, S., Go, S. Zinzow, H., Gray, A. \& Barrett, M. G. 2007. Analysis of strategic plans to assess planning for sustainability of comprehensive community initiatives. Evaluation and Program Planning, $30(1), 105-113$. 
10. UNCTAD. 2000. Cross-border Mergers and Acquisitions and Development. Geneva: United Nations.

11. UNDP. 2006. International Trade and Human Development Lao PDR 2006. Vientiane: UNDP.

12. World Bank. 2007. Cross-Border Trade Within the Central Asia Regional Economic Cooperation. Washington, DC: World Bank.

13. Yamane, T. 1973. Statistics: An Introductory Analysis. 3rd ed. New York: Harper \& Row. 
NOTES 